\title{
Influence of various preservative chemicals on postharvest life of cut roses (Rosa hybrida L.) cv. happiness
}

\author{
Virendra Pal ${ }^{1}$, Ashish Tyagi ${ }^{2}$ and Anant Kumar ${ }^{3}$ \\ 1 \& 2 Krishi Vigyan Kendra, Hastinapur, SVP Univ. of Agric. \& Tech., Meerut- 250110 (U.P.) \\ ${ }^{3}$ Krishi Vigyan Kendra, Ghaziabad, SVP Univ. of Agric. \& Tech., Meerut- 250110 (U.P.)
}

\begin{abstract}
An investigation was conducted to extend the vase life of cut rose cv. Happiness harvested at the three different stages by using various preservative chemicals. At the half open stage, 8 -HQC $100 \mathrm{ppm}+\mathrm{AgNO}_{3} 100 \mathrm{ppm}$, $\mathrm{AgNO}_{3} 100 \mathrm{ppm}+$ sucrose $2 \%$ and DMSO100 ppm + sucrose $2 \%$ extended the vase life to the maximum (12 day) while at full open stage, 8 -HQC $100 \mathrm{ppm}+\mathrm{AgNO}_{3} 100 \mathrm{ppm}+$ sucrose $1 \%, \mathrm{Al}_{2}\left(\mathrm{SO}_{4}\right)_{3} 200 \mathrm{ppm}+$ boric acid $100 \mathrm{ppm}$ maximum (12 day) the vase life of cut roses. None of the chemicals could significantly influence the post harvest life of flower at bud stage. Most of the chemicals improved water loss and water uptake ratio over control.
\end{abstract}

Keywords: Preservative chemicals, post harvest life, rose.

Paper cited: Pal, V., Tyagi, A. and Kumar, A. (2015). Influence of various preservative chemicals on postharvest life of cut roses (Rosa hybrida L.) cv. happiness. South Asian Journal of Food Technology and Environment, 1(3\&4): 274-278.

\section{Received: 10/11/2015 Revised: 23/11/2015 Accepted 27/11/2015}

\section{Introduction}

Cut roses are symbol of beauty, fragrance and are to convey the message of love. Great diversity in slow opening of flowers and good keeping quality made cut rose so popular that it is grown commercially to meet the demand of cut flower. The postharvest life and quality of cut flowers to a great extent is related with the turgidity (Rogers, 1973). Higher level of turgidity influences development of flower buds to fullopen maturity and normal metabolic activity in the cut flower. The turgidity in plants and flowers is dependent on the balance between water utilization or loss and water supply (Rogers, 1962). The short post harvest life of rose is determined by neck bending (Burdett, 1970), wilting of leaves and flowers and incomplete bud open, rapid loss of fresh weight (Aarts, 1957), water deficit (Rogers, 1973) and low turgidity (Mayak et al., 1974). The addition of chemicals including some trace elements to holding solutions were tried with varied success to extend the vase life of rose (De and Bhattacharjee, 1999). Aarts (1957) reported that uninterrupted water supply is major requirement for increased vase life. Standardization of methods for opening of tight bud stage in roses by use of nutrients and other chemicals are necessary to improve quality and longevity. Blockage is regarded as the major cause for wilting and reduction of longevity of cut flowers (Burdett, 1970; Rogers, 1973). Presently, research is being persuaded for opening of buds at different stages of maturity with chemicals in rose. The present investigation was carried out to study the effect of chemicals on extending the vase life of Happiness cut roses.

\section{Materials and Methods}

The investigation was carried out in the Department of Horticulture, C.C.S. Univ. Campus, Meerut during the 2005-06. The flowers were harvested when a flower buds were loose tipped but without unfurling petals and unfurled sepals remained at right angle to the axis of flowers - stage I, half open flowers - stage II and full open flowers - stage III. 
Uniform size of flowers were harvested and kept in tap water for 3-4 $\mathrm{h}$ at room temperature. The stems were cut at a uniform length of $45 \mathrm{~cm}$ and stripped of all except upper two leaflet leaves. Fresh weight of individual flower was recorded and kept into conical flask containing $250 \mathrm{ml}$ of aqueous solution of various chemicals and distilled water (control). There were six treatments including control viz., $\mathrm{T}_{1^{-}}$8-HQC 100ppm + $\mathrm{AgNO}_{3}$ 100ppm , $\mathrm{T}_{2}-\mathrm{AgNO}_{3}$ 100ppm + sucrose $2 \%, \mathrm{~T}_{3}-$ DMSO $100 \mathrm{ppm}+$ sucrose $2 \%, \mathrm{~T}_{4}-\mathrm{A}_{2} \mathrm{SO}_{4} 200 \mathrm{ppm}+$ sucrose $2 \%, \mathrm{~T}_{5}-$ $\mathrm{Al}_{2}\left(\mathrm{SO}_{4}\right)_{3} 200 \mathrm{ppm}+$ Boric acid $100 \mathrm{ppm}, \mathrm{T}_{6}-$ Distilled water (control). Three flowers were used for each concentration under each treatment and each flower represented one replication. At fixed time, the weight of each cylinder plus solution with or without flower was measured. The difference between consecutive measurements of the cylinder + solution without flower represents the water uptake, while the difference between consecutive measurements of cylinder + solution + flower represents the transpiration loss. In each flask, cotton plug was put to avoid evaporation loss. Bluish or darkening of petals was considered as the end of usual vase life of the flowers (Venkatarayappa et al., 1980). During the period of experiment, maximum temperature (average) was $24.6^{\circ} \mathrm{C}$ while minimum (average) was $18.7^{\circ} \mathrm{C}$. The average relative humidity was $65.8 \%$. The experiment was laid out in a completely randomized design and data were statistical analysed.

\section{Results and discussion}

Change in fresh weight: The investigation revealed that fresh weight of flowers on $3^{\text {rd }}$ day increased irrespective of stage of harvest and treatments (Table 1). The gain in fresh weight of flower was significantly different among the various treatments at stage III, but it could not show any significant variation among the treatments at the stages I and II though the fresh weight increased over control at both the stages. The fresh weight at stage III $(4.24 \mathrm{~g})$ increased at the application of $\mathrm{AgNO}_{3}$
$100 \mathrm{ppm}+$ sucrose $2 \%$. Better water conductance through stem due to germicidal properties of silver nitrate in addition to the ethylene inhibition might have helped in maximum uptake of water by the flower which resulted in gain in fresh weight. (De Stinger, 1980) also recorded that glucose, aluminium sulphate and 8 -HQC had a positive role in increasing fresh weight and water conductance of rose. The fresh weight of flowers at senescence also decreased profoundly and varied significantly among the treatments irrespective of the stage of harvest.

Sivasamy and Bhattacharjee (2000) reported that the fresh weight generally increased in first few days thereafter it decreased gradually till senescence. At senescence, 8-HQC $100 \mathrm{ppm}+\mathrm{AgNO}_{3} 100$ ppm recorded minimum weight loss $(2.48 \mathrm{~g}$, $2.03 \mathrm{~g}, 2.38 \mathrm{~g}$, respectively) at all the stages. 8 -HQC and silver nitrate play vital role in checking microbial growth in the holding solution thereby decreasing the loss in fresh weight of flower. The results are in close proximity with the findings of (Singh and Bhattacharjee, 2000). Earlier workers (Accati and Jona, 1989; Wu et al., 1991) predicted that higher amount of ethylene producing enzymes and ethylene is responsible for water loss. It appears that chemicals used for enhancing vase life improved the water uptake of cut flower by reducing the vascular blockage and ultimately changed the fresh weight of flowers.

Water uptake, water loss and water loss/uptake ratio: The water uptake was significantly influenced by various chemicals at all stages of harvest of flowers (Table 2). At stage I, maximum quantity of water $(8.65 \mathrm{~g})$ was absorbed at $8-\mathrm{HQC} 100 \mathrm{ppm}+\mathrm{AgNO}_{3}$ $100 \mathrm{ppm}$ which might be due to the same reasons stated earlier. Application of solution further improved the water uptake at stage II and stage III. It is interesting to note that at both the stages, water uptake was maximum (23.92 $\mathrm{g}$ and $24.37 \mathrm{~g}$, respectively) for 8-HQC $100 \mathrm{ppm}+\mathrm{AgNO}_{3} 100 \mathrm{ppm}$. Murr et al., (1979) reported that $\mathrm{CoCl}_{2} \cdot 6 \mathrm{H}_{2} \mathrm{O} \& \mathrm{AgNO}_{3}$ could increase the water uptake by stems 
thereby increasing the vase life of the flower. Microorganisms are considered to be one of the main causes of reduced water uptake by cut flowers, as germicides like 8-HQC and silver nitrate control microbial growth and partially reduced resistance to water flow (Aarts, 1957; Burdett, 1970).

The transpiration loss was also significantly influenced by the various solutions and followed the same pattern as that of water uptake. Although the water uptake and loss were higher in chemical treatments, the water loss and uptake ratio, an indicator of water balance was significantly lowered by all the concentrations of chemicals when compared with the control at all the stages of harvest of flowers. The water balance is a major factor influencing the quality and longevity of cut flowers of roses as recognized by so many workers (Aarts, 1957; Mayak et al., 1974; Roger, 1973). Water deficit of cut stem has a direct relationship with turgidity of cut flowers and will accelerate the senescence (Mayak and Halevy, 1972).

Water loss and uptake ratio were quite lower at all the treatments than in case of control at all the stages of harvest thereby maximizing the vase life.

In the present investigation, it has been demonstrated that chemicals effectively increased water uptake in all treatments than control. A significant decrease in water loss/ uptake ratio indicated better water retention by the treated cut flower. Venkatarayappa et al., (1980) reported that $\mathrm{CO}^{2+}$ improved the water retention as compared to untreated cut flower of rose and increased the water uptake. Chemicals strikingly affected the declining of fresh weight of cut roses and were found to be associated with reduced water loss/uptake ratio and an increased water uptake. Sacalis (1974) also reported similar observations.

The vase life of cut rose was significantly influenced by the application of chemicals at stage II as well as stage III, however, chemicals failed to improve the vase life at stage I. The vase-life was nine day at untreated flower in both the cases and all chemicals with given concentrations increased vase-life of rose cut flowers. At half open stage, 8-HQC $100 \mathrm{ppm}+\mathrm{AgNO}_{3} 100 \mathrm{ppm}$, $\mathrm{AgNO}_{3} 100 \mathrm{ppm}+$ sucrose $2 \%$ extended the vase life to the maximum (12 day) while at full open stage, 8-HQC $100 \mathrm{ppm}+\mathrm{AgNO}_{3} 100$ ppm , sucrose $2 \%+8$-HQC $100 \mathrm{ppm}$ and $\mathrm{Al}_{2}\left(\mathrm{SO}_{4}\right)_{3} 200 \mathrm{ppm}+$ boric acid $100 \mathrm{ppm}$ maximized (12 day) the vase life of cut roses. For both the stages, the maximum vase life (12 day) was recorded at 8 -HQC $100 \mathrm{ppm}+$ $\mathrm{AgNO}_{3} 100 \mathrm{ppm}$. Increase in vase life with 8$\mathrm{HQC}+\mathrm{AgNO}_{3}$ is because of their bactericidal properties (Mayak et al., 1994). $\mathrm{AgNO}_{3}$ has also been reported as an inhibitor of ethylene biosynthesis (Beyer; 1976). Cobalt also plays vital role in increasing vase life of cut roses by inhibiting vascular blockage Similar action of cobalt is also reported by earlier workers (Lau and Yang, 1976). Addition of sucrose might have provided the required amount of energy to at the bloom to remain it fresh for longer period of time. De Stinger (1980) also recorded that glucose, aluminium sulphate and 8-HQC increased fresh weight and water conductance of rose thereby extending senescence. It appears that chemicals used for enhancing vase life improved the water uptake of cut flower by reducing the vascular blockage and ultimately change the fresh weight.

\section{Conclusion}

Increasing vase life is the key issue in the post harvest management of cut flowers. Most of the chemicals exhibited positive effect in delaying senescence in cut roses by increasing the water uptake and improving the water balance, leading to increased fresh weight and vase life. Solution containing 8HQC $100 \mathrm{ppm}+\mathrm{AgNO}_{3} 100 \mathrm{ppm}$ improved vase life of cut rose cv. Happiness whether harvested half open stage or fully open stage. Though, other chemicals were also found to be beneficial in relation to extending vase life of rose. $\mathrm{Al}_{2}\left(\mathrm{SO}_{4}\right)_{3} 200 \mathrm{ppm}$, boric acid $100 \mathrm{ppm}$ in given combination enhanced vase of life of cut roses at both the stages of harvest. 
Table 1: Response of various preservative chemicals on fresh weight of flower in Rose cv. Happiness

\begin{tabular}{|c|c|c|c|c|c|c|}
\hline Treatments & \multicolumn{3}{|c|}{ Gain in fresh weight of flower on $3^{\text {rd }}$ day (g) } & \multicolumn{3}{|c|}{$\begin{array}{c}\text { Loss in fresh weight of flower on } \\
\text { senescence (g) }\end{array}$} \\
\hline 8-HQC $100 \mathrm{ppm}+\mathrm{AgNO}_{3} 100 \mathrm{ppm}$ & 0.88 & 1.86 & 3.95 & 2.48 & 2.03 & 2.38 \\
\hline DMSO 100 ppm + Sucrose $2 \%$ & 0.79 & 1.77 & 2.90 & 3.19 & 4.50 & 3.97 \\
\hline $\mathrm{Al}_{2}\left(\mathrm{SO}_{4}\right)_{3} 200 \mathrm{ppm}+$ Sucrose $2 \%$ & 1.53 & 1.33 & 3.36 & 2.81 & 4.86 & 3.96 \\
\hline $\mathrm{Al}_{2}\left(\mathrm{SO}_{4}\right)_{3} 100 \mathrm{ppm}+$ Boric Acid $100 \mathrm{ppm}$ & 1.26 & 1.27 & 3.02 & 3.83 & 3.34 & 4.07 \\
\hline C.D. $(5 \%)$ & NS & NS & 1.12 & 1.91 & 1.85 & 1.87 \\
\hline
\end{tabular}

Table 2: Effect of preservative chemicals on water uptake, water loss and water loss/uptake ratio in rose cv. Happiness (Vase life 12 days)

\begin{tabular}{|c|c|c|c|c|c|c|c|c|c|}
\hline Treatment & \multicolumn{3}{|c|}{ Water uptake up to senescence } & \multicolumn{3}{|c|}{$\begin{array}{l}\text { Water loss up to senescence } \\
\text { (g) }\end{array}$} & \multicolumn{3}{|c|}{ Water loss/ water uptake ratio } \\
\hline 8-HQC $100 \mathrm{ppm}+\mathrm{AgNO}_{3} 100 \mathrm{ppm}$ & 8.65 & 22.74 & 23.40 & 7.60 & 14.41 & 17.98 & 0.92 & 0.98 & 0.97 \\
\hline DMSO $100 \mathrm{ppm}+$ Sucrose $2 \%$ & 5.91 & 20.50 & 21.21 & 4.43 & 21.23 & 21.06 & 0.94 & 0.96 & 0.99 \\
\hline $\mathrm{Al}_{2}\left(\mathrm{SO}_{4}\right)_{3} 200 \mathrm{ppm}+$ Sucrose $2 \%$ & 3.50 & 17.88 & 18.08 & 3.53 & 22.08 & 20.98 & 0.93 & 0.99 & 0.96 \\
\hline $\begin{array}{l}\mathrm{Al}_{2}\left(\mathrm{SO}_{4}\right)_{3} 100 \mathrm{ppm}+\text { Boric Acid } \\
100 \mathrm{ppm}\end{array}$ & 4.54 & 21.23 & 21.80 & 4.08 & 17.76 & 16.97 & 0.93 & 0.98 & 0.99 \\
\hline C.D. (5\%) & 3.03 & 2.23 & 2.96 & 2.89 & 2.21 & 3.00 & 0.09 & 0.028 & 2.92 \\
\hline
\end{tabular}




\section{References}

1. Aarts, J.F.T. (1957). Over de houdbaaheid van snijbloemen (On keepability of cut flowers) Meded. Landbouwhogesch, 57: 1-62.

2. Accati, E.G. and Jona, R. (1989). Parameters influencing Rogers, gerbera cut flower longevity. Acta Horticulture, 261: 63-68.

3. Beyer, E.N. (1976). A potent inhibitor of ethylene action in plants. Plant Physiology, 58: 268-271.

4. Burdett, A.N. (1970). The cause of bent neck in cut roses. Journal of American Society of horticultural Science, 95: 427431.

5. De Stinger, H.N. (1980). Water balance aspects of cut and intact 'Sonia' rose plant and effects of glucose, 8-hydroquinoline sulphate and aluminium sulphate. Acta Horticulture, 113: 97-107.

6. De, L.C. and Bhattacharjee, S.K. (1999). Effect of chemicals for tight bud opening of rose cv. Super Sivasamy, N. Star at different stages of maturity. Annals of Agricultural Research, 20(2): 206-211.

7. Lau, O.L. and Yang, S.F. (1976). Inhibitor of ethylene production of cobaltous ion. Plant Physiology, 58: 114-117.

8. Mayak, S., Halevy, A.H., Sagie, S., Yoseph, A.B. and Bravdo, B. (1974). The water balance of cut rose flowers. Plant Physiology, 131: 15-22.

9. Mayak, S. and Halevy, A.H. (1972). Inter relationship of ethylene and abscisic acid in the control of rose petal senescence. Plant Physiology, 50: 341-346.

10. Murr, D.P., Venkatarayappa, T. and Tsujita, M.J. (1979). Counteraction of bent neck of cut roses with cobalt nitrate. Canada Journal of Plant Science, 59: 1169- 1171.
11. Rogers, M.N. (1962). Sell flowers that last, 8. Turgidity vital in vase life. Floriculture Review, 131 (3385): 29-30.

12. Rogers, M.N. (1973). A historical and critical review of post harvest physiology research on cut flowers. HortScience, 8(3): 189-194.

13. Sacalis, J.N. (1974). Inhibition of vascular blockage and extension of vase life of cut roses with an ion exchange column. HortScience, 9: 149-151.

14. Singh, D.C. and Bhattacharjee, S.K. (2000). Effect of pulsing with silver nitrate, STS and DM50 on Raktagandha cut roses. Journal of Ornamental Horticulture, 3(2): 131-132.

15. Sivasamy, N. and Bhattacharjee, S.K. (2000). Studies on vase life of rose cultivars. Journal of Ornamental Horticulture, 3 (2): 128-130.

16. Venkatarayappa, T., Tsujita, M.J. and Murr, D.P. (1980). Influence of cobaltous ion $\left(\mathrm{Co}^{2+}\right)$ on the postharvest behavior of Samantha roses. Journal of American Society of horticultural Science, 105: 148151.

17. Wu, M.J., Van Doorn, W.G. and Reid, M.S. (1991). Variation in the senescence of carnation (Dianthus caryophylius L.) cultivars. 1. Comparison of flower life, respiration and ethylene biosynthesis. Scientia Horticulture, 48: 99-107. 